\title{
Surfaces
}

\section{History and Narrative in Japanese}

\section{Chiyuki Kumakura}

Volume 5, 1995

\section{DEUXIÈME CONGRÈS INTERNATIONAL SUR LE DISCOURS HUMANISTE (1995)}

SECOND INTERNATIONAL CONFERENCE ON HUMANISTIC DISCOURSE (1995)

URI : https://id.erudit.org/iderudit/1065000ar

DOI : https://doi.org/10.7202/1065000ar

Aller au sommaire du numéro

\section{Éditeur(s)}

Les Presses de l’Université de Montréal

\section{ISSN}

1188-2492 (imprimé)

1200-5320 (numérique)

Découvrir la revue

\section{Citer cet article}

Kumakura, C. (1995). History and Narrative in Japanese. Surfaces, 5. https://doi.org/10.7202/1065000ar

\section{Résumé de l'article}

Cet essai analyse ce que Oe Kenzaburo (prix Nobel de littérature 1994) appelle les deux pôles opposés de l'ambiguité. La modernisation de la langue japonaise s'est orientée vers la connaissance et l'imitation des langues Indo-Européennes (ou bien le Chinois), lesquelles permettent de faire des constatations objectives. La langue japonaise (yamato kotoba) est orientée sans équivoque vers le point de vue de l'énonciateur, lequel est naturellement subjectif et reflète exclusivement ses propres perceptions et jugements. Pour Oe, l'orientation ambiguë de la langue japonaise a contraint cette culture à l'obscurité et à l'isolement. Mon analyse est que la nature « inter-personnelle » du Japonais (dérivée du point de vue de l'énonciateur) et la culture « inter-personnelle " (dérivée de la langue) a créé une culture qui apparaît ambiguë et souvent considérée impénétrable à partir d'une perspective européenne. Cette interpersonnalité, caractéristique de la culture et du discours japonais, est un nouveau concept qui mérite cependant d'être approfondi.
Ce document est protégé par la loi sur le droit d'auteur. L'utilisation des services d'Érudit (y compris la reproduction) est assujettie à sa politique d'utilisation que vous pouvez consulter en ligne.

https://apropos.erudit.org/fr/usagers/politique-dutilisation/ 


\section{History and Narrative in Japanese}

Chiyuki Kumakura

2-20-23- Tokiwadai

Itabasshi-ku

Tokyo 174

F00756@sinet.ad.jp

Surfaces Vol.V.206 (v.1.0A - 20/11/1995)

Copyright for texts published in SURFACES remains the property of authors. However, any further publication should be accompanied by an acknowledgement of SURFACES as the place of initial publication.

ISSN: $1188-2492$

\section{ABSTRACT}

This essay analyzes what Oe Kenzaburo (1994 Nobel laureate in literature) calls two opposing poles of ambiguity. The modernization of the Japanese language has been oriented toward learning from and imitating IndoEuropean languages (or Chinese), which permits one to make objective statements. Yet native Japanese (yamato kotoba) is unequivocally oriented by the speaker's standpoint which is naturally subjective, reflecting only his/ her perceptions and judgments. To Oe, this ambiguous orientation of the Japanese language has forced its culture into obscurity and isolation. In my analysis, the "interpersonal" nature of Japanese (derived from the speaker orientation) and the interpersonal culture of Japan (derived from the language) have created a culture that appears ambiguous and may often be considered inscrutable from a European perspective. However, interpersonality as a feature of Japanese culture and in Japanese discourse is a new concept that deserves further examination.

\section{RÉSUMÉ}

Cet essai analyse ce que Oe Kenzaburo (prix Nobel de littérature 1994) appelle les deux pôles opposés de l'ambiguïté. La modernisation de la langue japonaise s'est orientée vers la connaissance et l'imitation des langues IndoEuropéennes (ou bien le Chinois), lesquelles permettent de faire des constatations objectives. La langue japonaise (yamato kotoba) est orientée sans équivoque vers le point de vue de l'énonciateur, lequel est naturellement subjectif et reflète exclusivement ses propres perceptions et jugements. Pour Oe, l'orientation ambiguë de la langue japonaise a contraint cette culture à l'obscurité et à l'isolement. Mon analyse est que la nature "inter-personnelle" du Japonais (dérivée du point de vue de l'énonciateur) et 
la culture "inter-personnelle" (dérivée de la langue) a créé une culture qui apparaît ambiguë et souvent considérée impénétrable à partir d'une perspective européenne. Cette interpersonnalité, caractéristique de la culture et du discours japonais, est un nouveau concept qui mérite cependant d'être approfondi.

In his Nobel Prize address entitled "Japan, the Ambiguous, and Myself," Oe Kenzaburo made the following statement:

After a hundred and twenty years of its modernization since the opening of the country, contemporary Japan is split between two opposite poles of ambiguity. This ambiguity, which is so powerful and penetrating that it divides both the state and its people, and affects me as a writer like a deep-felt scar, is evident in various ways. The modernization of Japan was oriented toward learning from and imitating the West, yet the country is situated in Asia and has firmly maintained its traditional culture. The ambiguous orientation of Japan drove the country into the position of an invader in Asia, and resulted in its isolation from other Asian nations not only politically but also socially and culturally. And even in the West, to which its culture was supposedly quite open, it has long remained inscrutable or only partially understood. (Stockholm, December 7, 1994) 1

It seems to me that this "humanistic discourse" of Oe (especially his remark that Japanese culture has remained inexplicable to the West or at least until now has impeded Western understanding) ought to be focused upon in light of the theme of our conference. What precisely does Oe mean by the words "polarity" and "cultural obscurity"? I do not think he successfully elucidates those terms, ultimately remaining "ambiguous" himself.

About three years and ago in New York, as if he had known that he was going to receive a Nobel Prize soon, he gave a speech entitled "Not as the Japanese in Closed Circuit (Kairo o tojita nihonjin to shite de wa naku)" in which he commented on the Nobel Prize address by Kawabata in 1972 entitled "Japan, the Beautiful, and Myself." Oe said that Kawabata's speech was ambiguous and obscure, and that it almost defied understanding by the West. Among Oe's remarks was the following:

It seems right to me to talk about the peculiarity of modern/ contemporary Japanese literature in order to explicate "Japan, the ambiguous, and myself". ... In the course of Japan's modernization, there was a radical revolution in literary language initiated by Futabatei Shimei

and completed by Natsume Soseki... .

Soseki wrote of intellectuals who had become unable to act in the wake of Japan's rapid modernization and Westernization. . . . Soseki's critical view of modern Japan remains a problem today. 
But you in the United States who have read Soseki may have felt that he never tried to speak to you or address Western concerns. Just as Kawabata's "Japan, the Beautiful, and Myself" was closed within itself, Soseki's work (which may perhaps be summarized as "Japan, the Distressed, and Myself") never tried to undertake a discourse with the West... .

Oe goes on to say in that speech in 1993 that not only Soseki but even such representative post-1945 figures as Mishima Yukio and Abe Kobo failed to make an effort to define Japan and the Japanese for the West. Their literary circuit too was completely closed. The Japanese have remained silent to the present day in spite of the fact that the Japanese economy prides itself on its position in the West. "The Japanese," says Oe, "may look like invisible men to you Americans. So, despite my poor English, I now feel obliged to speak up and explain Japan and Japanese culture to the West."

Oe is to be congratulated for his lofty aims. But has he really gone on to clarify the matter in his Nobel Prize address or elsewhere? I think he remains vague and obscure. He is not, however, entirely to blame for this failure. The reason for the silence of the Japanese or the apparent inscrutability of Japanese culture lies, I believe, in the inescapable nature of the Japanese language. The truth of the matter is that the native Japanese language differs from Indo-European languages (and for that matter from Chinese) in ways so fundamental that the Japanese in the past have never been able to define or clarify themselves and their culture adequately in European languages. Conversely, the West has never been able to understand Japan on its own terms. The disjunction seems to prove the Sapir-Whorf hypothesis, which holds that cultural products (humanistic discourses, if you will) are affected and limited by the nature of the language in which they are expressed.

Oe went on to remark in this respect that had the late Abe Kobo lived longer, he might have gone on to solve the problem by developing a kind of literary language that could be understood universally. In his lecture "Can World Literature Become a Japanese Literature?" Oe himself dreams of a "world language" (sekai gengo) to replace Japanese. Apparently, Oe agrees with Abe that the Japanese language is "limited." Today, therefore, I would like to consider exactly how Japanese is limited and how that limitation becomes problematic for humanistic discourse.

\section{The Japanese Language and Time}

It is my belief that the Japanese language-and consequently Japanese literary discourse (and for that matter, other forms of artistic discourse)has only one point of view, which is the speaker's. I will go on later to characterize this speaker's point of view as actually "interpersonal," and stress that it differs radically from the "first person" and "third person" in Western languages. Indeed, the fact that there is no grammatical "person" at all in Japanese itself militates against any direct comparisons between Japanese and a language like English. 
The term "point of view" is defined by Webster's New World Dictionary asfollows: 1 . the place from which, or way in which, something is viewed or considered; standpoint; 2 . a mental attitude or opinion; 3 . the viewpoint from which a story is narrated (e.g., omniscient point of view).

Definition 1 refers to the way something is considered, whereas definition 2 refers to an end, such as "my point of view," an opinion acquired through personal observation. Definition 3 encompasses both definitions 1 and 2 in the sense that it is concerned with both how a story is narrated and what it is all about.

These definitions may or may not be applicable to Japanese because the language contains no point of view other than the speaker's. Every speaker of Japanese does so from his/her standpoint and from that standpoint only. Definition 1 above (the standpoint), then, would seem to be severely "limited" because there are no other points of view such as "third person" and "omniscient." By the way, the word for "to speak" in Japanese [hanasu] is etymologically the same as "to release" [hanasu]. In other words, speaking in Japanese is "releasing" or "letting go of" what the speaker has in mind. Therefore, definition 2 (the end of the point of view, the opinion) is also limited because the speaker's observation and emotion are all coming from within, and there is no frame of reference available (sources of "objective" comparison). If this is the case, then definition 3 must be naturally limited to the speaker/narrator.

I refer to this Japanese point of view as that of the speaker, and I call the language (and by extension, Japanese humanistic discourse) "speakeroriented." I will now enumerate important features of the language which generate this point of view and, subsequently, the speaker-oriented narrative voice in Japanese literature:

1. Every verb in the language is a record of the speaker's perception or observation. Such a phenomenon is not limited to those verbs which clearly have the speaker's point of view such as $i k u$ (to go), kuru (to come), yaru (to give), morau (to receive), etc., but extends to all others such as furu (to fall) and a second furu (to become old) [the former meaning that the speaker observes something "passing in space" and the latter "passing in time"], hence facilitating the pivotal expression: wagami yo ni furu nagameseshi ma ni (I have become old while watching the long rain) (Kokinshu 113);

2. Adjectives are also oriented in terms of the speaker. Again, these are not limited to the so-called shiku-katsuyoo adjectives (kanashii [sad], ureshii [happy], etc., which indicate the speaker's emotive reactions) but extend as well to the ku-katsuyoo adjectives such as akai [red], takai [high], ookii [large], etc., which indicate the speaker's sense reactions. In other words, Japanese adjectives are not objective descriptions of outer reality as in European languages but record the speaker's reactions to the reality s/he perceives. When a Japanese speaker touches a hot coffee mug and says atsui, the adjective does not mean that the mug itself is "hot"; rather, it is an expression of the speaker's perception of the mug s/he has touched. 
3. The so-called relationals are "speaker-oriented" as well. Typically, the sentence-ending relationals such as sa [I judge], yo [I tell you], ne [I make sure], etc., indicate the speaker's attitude or emotional involvement in the idea preceding the relational. Other relationals that appear "objective" such as the topic marker wa or the nominative case marker ga are no exceptions. For example, ocha (tea) in a sentence ocha ga hoshii (I want tea) marks the nominative case to which the speaker's emotion-hoshii-is attributed.

4. Temporal aspects: the time expressed in a Japanese sentence is also oriented to the speaker's present moment, which may or may not coincide with the objective time that governs the tense and aspect in similar expressions in European languages (I shall elaborate on this shortly).

5. Syntax: word order in Japanese follows the speaker's internal reality, recording events (actual or imagined) in the chronology in which they occur in his/her mind and placing them in the (internal) present. Thus, reality is only personal (psychological), and not reconstructed objectively as in European languages. Narrative time in Japanese, both story time and narrating time, is in harmony with the basic syntactical (personal) order in Japanese.

6. Other features such as the existence of elaborate honorific expressions, the so-called ko-so-a-do system, and onomatopoetic words (giongo/ gitaigo), and the lack of personal pronouns all indicate the presence of the speaker.

Japanese verbs are inflected to differentiate what the speaker observes moment by moment. Therefore, the time expressed in a Japanese sentence is fixed at the speaker's present moment. In fact, inflected forms such as mizen [yet to realize], renyoo [just realized], shuushi [being realized]) indicate the aspects of an event as the speaker recognizes and verbalizes them moment by moment. They are differentiated phonetically by vowels. For example, at the moment when a phenomenon appears and is recognized by the speaker, the image is concretized in his mind and expressed with the vowel /i/ (renyoo). But when a phenomenon has yet to happen, in other words, if the speaker does not recognize a phenomenon (in cases of negation, assumption for the future, etc.), the image is expressed with the vowel /a/ (mizen), which is "open" phonetically as opposed to the "closed" vowel /i/.

Thus, the Japanese verb system functions not in terms of "person" like European languages but in terms of the ways phenomena are perceived by the speaker. For this reason, Japanese time consciousness is focused only at the moment of perception /recognition, and therefore, there is only one moment, and one moment only, namely the present time that is crucial in Japanese. This "presentness," furthermore, exists only in the speaker's mind. Consequently, unlike in European languages, there is no "tense" system in Japanese to place historical events objectively in a discourse. In short, there is no way of writing "history" in Western sense of the word.

In English, tense is defined as "a distinction of form in a verb to express distinctions of time." On the other hand, the -ta form in modern Japanese 
was derived from tari, a classical verb suffix, that signifies "continuous existence after a completed action (or movement) [kanryoo no sonzoku]." The -ta form would seem to signify, therefore, that the speaker recognizes the "existence" of an image which has already completed its action (or movement) at speech time. Naturally, the action completed prior to the speech time is now "past," but the essential function of the - -ta form is not to indicate the "past" tense but to make the subject (or object) of the action "exist" at the focal point of the narrative present. The temporal sense of -ta, then, always involves the "current" narrative time. The secondary meanings in the -ta form, i.e., "completion" and "past," are often difficult to determine in the text, perhaps for a good reason: it does not matter whether the event is in the past or in the completed state insofar as the image "recollected" exists in the narrator's mind at speech time. To recollect past events is certainly not the same as "to express distinction of time," especially when "past time" is neither objective nor physical and exists only in the narrator's mind. Thus we may or may not be able to use the term "tense" when we deal with the Japanese language.

\section{History in Japanese}

In Japanese, representation of past events requires an observer of the events who has experienced them personally and therefore is able to relate them. For this reason, in Ookagami (a twelfth-century "historical tale" [rekishi monogatari]), two men who are each one hundred and ninety years old serve as narrators. They are necessary in order to assert the truth of the events. But, however truthfully they try to "represent" the events, they can do so only from their "present" point of view, depending heavily on their individual ability to recollect the events to begin with and, further, to "speak of" ("release") the events. Let me reiterate that the "events" thus recollected are in many ways highly subjective because they are "speaker-oriented." Japanese time and Japanese narrated events, therefore, are not "historical" in the Western sense, because they do not really "represent" the outer world but only reflect the world as it exists in the observer's mind. /pp. 11-12/

One good example to illustrate this point is Murakami Haruki's best-selling novel Norwegian Wood.2 The main character-narrator is a thirty-seven year old Japanese who is disturbed by heating the Beatles' tune "Norwegian Wood" as his plane is about to land at Hamburg Airport. The tune reminds him of his past, his college years, and he then flashes back nineteen years and recollects the student turmoil around 1969. The rest of the story recounts what he did during that era, what he discussed with friends, what he wrote in his letters, and so on, almost verbatim, page after page. If these recollected events had been historical facts that he somehow recorded and kept with him for almost two decades, then he could have used them to plausibly "represent" his story at the narrative present and the reader would have accepted his narrative discourse as authentic and trustworthy. However, Murakami makes no such attempt to prove his tale's "historicity," and his entire narrative therefore rings false. The English translation by Alfred Birnbaum treats the introductory part (i.e., the hero's landing at the airport) in the present tense and the rest in the past, which naturally makes the whole story much more truthful, yet the problem of authenticity remains 
because no one in the world can recollect in minute details the events that occurred over a span of many months and almost two decades prior to the narrating time.

By contrast, I find the short story "Blackbird Pie" (1989) $\underline{3}$ by Raymond Carver (1939-88) to be an ideal example of both historical authenticity and the problem of recollection and representation. It so happens that Murakami admires Carver so much so that he has been translating Carver's works for the last eight years or more. He has produced five volumes so far and has two more to go. His translation of "Blackbird Pie," however, reads dreadfully because he altogether misunderstood the story's theme and metaphors. /pp. $12-13 /$

Carver's autobiographical narrator, realizing that he has cancer and has only a few more months to live, decides to write an autobiographical story (which is not Carver's usual mode of fiction). It is the story of a man whose wife suddenly announces that she is leaving him. The story opens with a mysterious letter put under the door of the narrator's study after dinner one foggy night. The letter is written in longhand, apparently by his wife, and yet not in her familiar handwriting. After he reads the following ("We've been together a long time-thick and thin, illness and health. . . high times and low. Now? Well, I don't know what I can say now except the truth: I can't go it another step"), he finds his wife, wearing a funeral hat, in the front yard with two horses. Shortly after that, a rancher who has lost the horses arrives at the house in the company of a deputy sheriff to recover them. There is a humorous conversation among the four people (a more or less typical American family scene, except that all the characters apart from the narrator-husband are wearing hats), and the wife is eventually given a ride in the rancher's trailer truck. After she is gone, at the end of the story, the narrator ponders:

There's still the question of the handwriting. That's a bewilderment. But the handwriting business isn't the important thing, of course. How could it be after the consequences of the letter? Not the letter itself but the things I can't forget that were in the letter. No, the letter is not paramount at all-there's far more to this than somebody's handwriting. The "far more" has to do with subtle things. It could be said, for instance, that to take a wife is to take a history. And if that's so, then I understand that I'm outside history now-like horses and fog. Or you could say that my history has left me. Or that I'm having to go on without history. . . That's when it dawns on me that autobiography is the poor man's history. And that I am saying good-bye to history. Good-bye, my darling. (emphasis Carver's)

Murakami's translation of "Blackbird Pie" with his lengthy commentary first appeared three years ago (Shincho, January, 1993) and was included in his last volume of Carver translations (March, 1994). In his commentary (in both the magazine and the volume), Murakami honestly expresses his "bewilderment" with regard to the meaning of the words in the last paragraph, and he concludes with a typically emotional Japanese statement to the effect that the third to the last sentence ("That's when it dawns on me 
that autobiography is the poor man's history") "clearly" expresses Carver's self-mockery (jichoo) of the fiction that he is going to leave behind.

Murakami writes:

Carver seems to be quietly saying that, compared to understanding and loving real people, writing fictitious stories is of little worth. When he says "Good-bye, my darling," he is really addressing you and me. Even if he has some specific "darling" in mind, that person and you and me are mingled together in his last world and understand each other. That's when salvation comes for the first time. . ."

One can almost hear Carver protest. The theme of this story is exactly the opposite of Murakami's interpretation. "History" itself (and not "you and me") has been Carver's "wife." Carver is quietly saying "good-bye" to his lifelong companion, that is, his "history," his stories. Murakami, a graduate of the department of French literature at Waseda University, has apparently forgotten his French: "histoire" in French means both "story" and "history." In fact, Carver's stories are the contemporary history of ordinary people in America. His mode of story writing could be interpreted as history in the sense that it attempts to represent real people and the truth of the times. What Murakami completely misinterpreted (the passage "to take a wife is to take a history") was intended to be a purely abstract idea, not a real "person." The dying Carver (Murakami himself reminds us emphatically that this was the second to last story Carver wrote), sensing that he was close to the end of his ability to write, decided to produce something other than a "history.""Blackbird Pie," therefore, must be read as an autobiographical story, a "poor man's history," which must sadly witness and chronicle the death of a historian [story writer]. $\underline{4}$

The story is full of metaphors, and Murakami pays little attention to them. I will quote only one, as a requiem for the author-a metaphor apparently innocent but truly moving:

As far back as what might be called our pre-history days-the time she went away to school as a girl, wearing a gray-and-white school uniform. She wrote letters to me every day that she was away. . . Altogether, in the course of our relationship, I would estimate (a conservative estimate, too), counting our separations and the short periods of time I was away on business or in the hospital, etc.-I would estimate, as I say, that I received seventeen hundred or possibly eighteen hundred and fifty handwritten letters from her. .. (emphasis mine)

Although Murakami recognized the phrase "pre-history days" as significant (and the word "letters" as also having to do with "man of letters"), he still managed to miss the meaning of the "gray-and-white uniform" (more on that in a moment). This raises a very serious question: have we Japanese ever really learned Western languages, either for everyday use or, more importantly, for cultural and literary use? If not (as Murakami's misreading fortuitously reveals), exactly what prevents us from learning them? 
Like a vicious circle, we must return to the notion of this speaker-oriented language of ours. It would seem that the Japanese language is unable to handle abstract thoughts. The reason for this is multifaceted: 1) time and space in the Japanese mind are limited only to the "present" and the "concrete," and, further, the presentness and concreteness are only reflections of an "inner" reality (i.e., the speaker, blended with Murakami's "you and me" and "salvation"); 2) the language cannot "represent" the past because it has no tense, no way to objectify "outer" reality; and 3) as a consequence, it cannot transform the concrete into the abstract because only the concrete and phenomenal are presupposed in the language. Thus, the image of "wife" must remain as a "flesh-and-blood" figure forever in Murakami's mind, and a "gray-and-white school uniform" can never be elevated to the higher, more abstract level of "pencil-and-paper." Japanese writers have never really written historical discourses. Have they, for that matter, written any philosophical discourse at all? If so, what kind? And what of "humanistic discourse"?

\section{Discourse (Narrative)}

It is easy to dismiss Murakami as simply a sloppy writer and translator. But most Japanese writers simply do not have good resources for handling temporal/historical perspective. Raymond Carver, on the other hand, is extremely careful to shape his narrator authentically. At the beginning of "Blackbird Pie," before he quotes his wife's letter, he establishes his credibility:

In any case, I have a good memory. I can recall every word of what I read. My memory is such that I used to win prizes in school. . . the details of the Council of Trent or the Treaty of Utrecht, or to talk about Carthage. . . .

Things stick in my head. I remember. So when I say I can recreate the letter. . I mean what I say.

In part, the letter went as follows. . .

Discourse in Japanese (i.e., narrative with a flesh-and-blood narrator), we now have to assume, may well be handicapped, limited only to the speaker's (narrator's) private time and space. As a rule "narrative time" in a Western narrative is a composite of two kinds of time - "story time" (the time in which events of a story take place) presented in the past tense, and "narrating time" (the time in which the narrator tells the story) presented in the present tense. Since "story time" occurs prior to "narrating time" in the "objective" (past-present-future) order of time, it is reasonable to expect "story time" to be represented by the past tense, while "narrating time," which reflects the narrator's telling (of the story) "now," would be in the present tense. In the Japanese narrative, however, both narrating time and story time are presented at the speaker's present time because, as I explained earlier, that is the only time that exists in Japanese. Narrative time in Japanese literature, or in other arts for that matter, is governed by one and only one point in time, which results in the temporal focus being on the narrator's internal "present" moment with no linguistic distinction between 
narrating time and story time (here lies the cause of a taken-for-granted representation of the past in Murakami's Norwegian Wood). The problem, then, lies in the fact that Japanese has no temporal perspective with which to place past events into a historical framework and, moreover, that there is no objective system of grammatical person (such as "first person" and "third person") to represent the space in proper spatial perspective. In all aspects of narrative discourse, temporal or otherwise, an objective point of view comparable to the one found in Western narrative is simply not viable in the Japanese counterpart. Neither Japanese-English translation nor the reverse is practicable when we realize this gigantic limitation of Japanese concerning outer reality.

The Western-style novel in Japanese, having a quasi-omniscient point of view (which has been idealized by many modern writers since the Meiji era) may or may not succeed. In fact, the Japanese language guarantees that novels written from the speaker-narrator's point of view (as in the so-called "Inovel" or shishoosetsu mode) will be effective, whereas any novel which attempts to create an artificial point of view in Western style is likely to fail. It would seem natural, therefore, that in Japanese narrative we must always recognize a flesh-and-blood narrator whose time consciousness governs the narrative flow, contrary to the claim made by Professor S.-Y. Kuroda $\underline{5}$ and others. According to Kuroda's theory, modern narrative may not have a narrator, for it "goes beyond the sphere of communication (discourse)." However, if every aspect of the Japanese language is fundamentally "speaker-oriented," Japanese narrative must remain within the field of communication (discourse) in which a speaker and listener are always found. It has been said that modern Western narratives have succeeded in representing the world in terms that may be independent from the observer's (reporter's) eye. In contrast to this, the Japanese world would not exist without the speaker's observation and cognizance. It appears clear to me, therefore, that Japanese narrative cannot and should not silence the narrator's voice.

Japanese lacks the very tools for creating omniscience. No matter how eagerly and vigorously the Japanese borrow expressions and techniques from Chinese and/or European languages, it is virtually impossible to create the Western voice. Japanese lacks just about every necessary ingredient, beginning with the six personal standpoints of the verb system as in German or French for the creation of such an orientation.

\section{Interpersonality}

The situation for the Japanese language, however, is not entirely dim. The potential to express inner reality that the Japanese language has developed over the centuries are, in fact, valuable aspects of Japanese culture. I would now like to discuss the nature of the Japanese speaker's consciousness. I said at the outset that the Japanese "person" is "interpersonal," that is, that his or her consciousness always contains the consciousnesses of others, and thus s/he cannot be an "individual" as defined in the Western sense but can only have a "collective" personality which goes /pp. 18-19/ beyond the boundaries of the Western individual. It makes sense then that the definition 
of human beings in Japanese is ningen ("among persons = interperson"), symbolically suggesting that the locus where a Japanese person resides psychologically is indeed in the midst of people. Transforming this phenomenon into the mode of narration, the narrator in Japanese can assimilate other characters, "representing" or "imitating" their consciousnesses. This aspect of the multifaceted consciousness, derived undoubtedly from the fact that every speaker in Japanese has the same standpoint, enables the narrative to achieve a degree of empathy of which no European narrative is capable.

In order to show that no fundamental change has occurred in the nature of the Japanese speaker's voice for centuries, I will quote a short passage from a noh text. Generally, the so-called waki character in noh is a superb example of a "participating narrator."

In Western theater, characters are presented as independent entities, who speak for themselves without any mediator. In the dream (mugen) plays of the noh theater, however, in which a traveling monk fantasizes and dreams of historical or legendary characters, the monk (the waki [subordinate] character) is the sole flesh-and-blood character in the play. What the audience watches on stage is a "presentation" of his inner voice or his "stream of consciousness," if you will. This extremely interesting mode of narrative voice ultimately transcends the monk's consciousness and achieves a metamorphosis, becoming the consciousness of the shite [the main character] as well. Often, the transition of consciousness from waki to shite occurs within a sentence, at which point the shite's voice is generated from within the monk's consciousness and projected visually onto the stage. Consider the following example from the play Nonomiya: $\underline{6}$

Priest (waki)

sa mo are ikanaru kuruma ya ran

Miyasudokoro (shite)

ikanaru kuruma to

towasetamaeba

omoi no izuru sono mukashi.

‥

koto ni tokimeku

Aoi no ue no

Priest

okuruma tote

hito o harai ... .
But what is the carriage you ride in?

You ask about my carriage?

I remember now

That scene of long ago. . .

And one among them of special magnificence

Princess Aoi's.

"Make way for Her Highness's carriage!"

The servant cried, clearing the crowd. . . 
The phrase "Aoi no Ue no/okuruma" ("Princess Aoi's carriage") in the above passage has been produced by two characters, Miyasudokoro (the shite) and the Priest (the waki) but in actuality it is the Priest's mind which produces the image of the carriage, and the entire dialog is a stream of consciousness which the waki's mind develops. What the audience observes, then, is not the real world but only the psychological reality of the waki's consciousness. Meanwhile, the audience must assimilate the monk's mental activity as he fantasizes or dreams of the shite character. Noh demands rigorous audience participation without which the play becomes unintelligible and loses its raison d'être altogether. And this kind of discourse would seem to illustrate what remains "obscure and inscrutable" about Japanese culture.

In any case, the Japanese narrator is not simply someone who speaks Japanese, but an interpersonal persona who is not omniscient but who can often transcend individual consciousness. The speaker in Japanese is not an autonomous 'person' or 'individual' and may not necessarily be speaking for himself as would a speaker in Western languages. Herein lies, I believe, the source of the "ambiguous" Japanese "personality" or "individuality."

However, interpersonality in Japanese culture and in Japanese discourse is perhaps a new value that the West could profitably examine.

\section{NOTES}

1 Kenzaburo Oe, "Japan, the Ambiguous, and Myself," in Japan, the Ambiguous, and Myself-The Nobel Prize Speech and Other Lectures (Kodansha International, 1994), p.117.

2 Haruki Murakami, Norwegian Wood, tr. Alfred Birnbaum, 2 vols. (Kodansha International, 1989).

$\underline{3}$ Raymond Carver, "Blackbird Pie" in Where I'm Calling from (Random House, 1989), pp.491-511.

$\underline{4}$ The horses and the two vehicles coincide with the wife's leaving in order to symbolize the power that carries the "wife," that is, story writing. The unusual handwriting refers to the unaccustomed literary style, this being a rare autobiographical account by the author. And the hats symbolize a literary funeral.

$\underline{5}$ S.-Y. Kuroda, "Reflections on the Foundations of Narrative Theory from a Linguistic Point of View," in The (W)hole of the Doughnut, Syntax and its Boundaries (E. Story-Scientia P.V.B.A: Ghent-Antwerp-Brussels, 1979).

6 Nonomiya, tr. Paul Varley, in Twenty Plays of the No Theatre, ed. Donald Keene (Columbia University Press, 1970). 